Manufacturing Execution Systems

Liezl van Dyk

Presented in partial fulfilment of the requirements for the degree

Master of Engineering

IN THE FACULTY OF ENGINEERING

DEPARTMENT OF INDUSTRIAL AND SYSTEMS ENGINEERING

UNIVERSITY OF PRETORIA

SEPTEMBER 1999 


\title{
ABSTRACT
}

Title:

Manufacturing Execution Systems

Author: Liezl van Dyk

Supervisor:

\author{
$C$ de $\mathbf{W}$ van Schoor
}

Department:

Industrial and Systems Engineering

Degree:

\section{Master of Engineering}

The term Manufacturing Execution Systems (MES) was created in 1990 by Advanced Manufacturing Research (AMR) to describe the suite of software products which enables the execution of manufacturing through the integration of planning and control systems.

The purpose of this dissertation is to determine the current status of MES and to investigate the possible role of the Industrial Engineer in the development, implementation and use of MES. To achieve this objective, the most commonly accepted, recent and relevant definitions, business models, functions and developments of MES are investigated. Based on these, a new MES Function Matrix is developed and validated by a case study. Finally, Industrial Engineering is related to MES and the role of the Industrial Engineer promoted.

The emergence of MES is a result of the evolution of three interrelated elements, namely manufacturing strategies, manufacturing planning and control systems and information technology. The development of global markets and the requirement for agile manufacturing led to the need for MES.

The evolution of various aspects of Enterprise Resource Planning (ERP), and more specifically Manufacturing Planning and Control (MPC) systems, is discussed as part of the investigation of the development of MES. The Three-Layer-model and REPACmodel by AMR Research, as well as variations of these models compiled by MESA ("International MES Association"), are investigated. Manufacturing execution is absent in traditional MPC models. Modern models, such as the Three-Layer-model, suggest an execution layer to be inserted between the planning and control layers. 
The investigation of the function models of McClellan and MESA International indicates that discrepancies exist between these models with regard to the functions of MES. A new MES Function Matrix is developed to address such shortcomings and is applied to a case study of DIAMES, a software product used by Aberdare Cables and promoted as an MES product.

As an MES developer, the Industrial Engineer can act as designer, planner and innovator. The greatest value can, however, be added by the Industrial Engineer as integrator to ensure that horizontal plant-wide execution takes place, and not only vertical "islands of automation" integrated with planning systems. In order to accomplish this, the Industrial Engineer needs to fulfill the roles of boundary-spanner, facilitator, coordinator, analyst, chairperson, decision-maker, as well as trainer or educator. MES can also be used by the Industrial Engineer as a tool, for example as part of a program of continuous improvement.

The identification of the relationship between the expertise of the Industrial Engineer and the roles to be played within the MES arena gave birth to the establishment of an MES research initiative at the Department of Industrial and Systems Engineering of the University of Pretoria.

\section{Key Words:}

- Manufacturing Execution Systems (MES)

- Industrial Engineering (IE)

- Enterprise Resource Planning (ERP)

- Control Systems

- Manufacturing Planning and Control Systems (MPC)

- Information Technology (IT)

- Manufacturing Systems

- Supply Chain Management (SCM)

- Business System Integration

- Agile Manufacturing 


\section{OPSOMMING}

Titel: Vervaardigingsuitvoeringstelsels

Outeur: $\quad$ Liezl van Dyk

Leier: $\quad C$ de $W$ van Schoor

Departement: Bedryfs-en Sisteemingenieurswese

Graad:

Magister Ingenieurswese

Die term Vervaardigingsuitvoeringstelsels ("Manufacturing Execution Systems" - MES) is in 1990 deur Advanced Manufacturing Systems (AMR) geskep om die sagtewareprodukte te beskryf wat die uitvoering van vervaardigingsplanne, deur die integrasie van beplanning- en beheerstelsels, moontlik maak.

Die doel van hierdie verhandeling is om die huidige status van MES te bepaal en die moontlike rol van die Bedryfsingenieur in die ontwikkeling, implementering en gebruik van MES te ondersoek. Om hierdie doel te bereik word die algemeen aanvaarde, resente en relevante definisies, besigheidsmodelle, funksies en ontwikkelings van MES ondersoek. Gebaseer hierop is 'n nuwe MES Funksionele Matriks ontwikkeling en getoets met ' $n$ gevallestudie. Laastens word die verhouding tussen MES en Bedryfsingenieurswese bepaal en die rol van die Bedryfsingenieur uitgebou.

MES is ' $n$ resultaat van die evolusie van drie verwante aspekte, naamlik vervaardigingstrategieë, vervaardigingsbeplanning en -beheerstelsels en inligtingstegnologie. Die opkoms van globale markte en die vereiste vir buigbare, ratse vervaardiging ("agile manufacturing") het aanleiding gegee tot die behoefte vir MES.

Die evolusie van verskeie aspekte van besigheidshulpbronbeplanning (ERP), en meer spesifiek vervaardigingsbeplanning- en beheerstelsels (MPC), word bespreek as deel van die ondersoek na die ontwikkeling van MES. Die Drie-Vlak-model en die REPACmodelle van AMR Research, asook variasies daarvan soos opgestel deur MESA ("International MES Association"), is ondersoek. Vervaardigingsuitvoering is afwesig in die tradisionele modelle van vervaardigingsbeplanning en -beheer. Moderne modelle, 
soos die Drie-Vlak-model, stel voor dat ' $n$ uitvoeringsvlak tussen die beplanning- en beheervlakke ingevoeg word.

Die ondersoek van die funksionele modelle van McClellan en MESA dui aan dat verskille bestaan ten opsigte van die funksies van MES. ' $n$ Nuwe MES Funksionele Matiks is ontwikkel om hierdie tekortkominge aan te spreek en word getoets in ' $n$ gevallestudie van DIAMES, 'n sagteware-produk wat by Aberdare Cables gebruik en as 'n vervaardigingsuitvoeringstelsel (MES) bemark word.

As ' $n$ MES-ontwikkelaar kan die Bedryfsingenieur optree as ' $n$ ontwerper, beplanner en innoveerder. Die grootste waarde kan egter deur die Bedryfsingenieur bygevoeg as integreerder, deur te verseker dat horisontale, aanlegwye uitvoering plaasvind en nie alleen vertikale "eilande van outomatisering" nie. Om dit te bereik, moet die Bedryfsingenieur die rolle vervul van brugbouer, fasiliteerder, koördineerder, analis, voorsitter, besluitnemer en opleier. MES kan ook deur die Bedryfsingenieur gebruik word as gereedskapstuk, byvoorbeeld as deel van 'n program vir kontinue verbetering. Die identifisering van die verwantskap tussen die kennisvelde van die Bedryfsingenieur en die rolle in die MES-arena het aanleiding gegee tot die vestiging van " $n$ MESnavorsingsinisiatief by die Departement van Bedryfs- en Sisteemingenieurswese van die Universiteit van Pretoria.

\section{Sleutelwoorde:}

- Vervaardigingsuitvoeringstelsels

- Bedryfsingenieurswese

- Besigheidshulpbronbeplanning

- Beheerstelsels

- Vervaardigingsbestuurstelsels

- Informasietegnologie

- Vervaardigingstelsels

- Voorsieningskanaalbestuur

- Besigheidstelselintegrasie

- Aanpasbare vervaardiging 


\section{TABLE OF CONTENTS}

\section{INTRODUCTION 1}

1. 1. PROBLEM STATEMENT

1. 1.1. MES DEFINITIONS AND BUSINESS MODELS

1. 1.2. MES AND THE INDUSTRIAL ENGINEER

1. 1.3. THE NEED FOR MES AWARENESS AND EDUCATION IN SOUTH AFRICA

1. 1.4. DEVELOPMENTS CONCERNING THE ORIGINAL PROJECT

1. 2. RESEARCH PURPOSE AND LIMITATIONS 1. 2.1. LIMITATIONS

1. 3. RESEARCH STRATEGY, STRUCTURE AND CONTRIBUTION

1. 3.1. CONTRIBUTIONS MADE THROUGH THIS RESEARCH

1. 3.2. STRUCTURE AND SCOPE

1. 4. RESEARCH METHODOLOGY

1. 4.1. GATHERING OF INFORMATION

1. 4.2. APPLYING INFORMATION

2. 1. CURRENT MES BUSINESS MODELS

2. 2. DATAFLOW BETWEEN MES AND NEIGHBOURING SYSTEMS

2. 2.1. DATA FLOW BETWEEN MES AND CONTROL SYSTEMS

2. 2.2. DATA FLOW BETWEEN MES AND PLANNING SYSTEMS

2. 3. THE REPAC MODEL

2. 3.1. THE RELATIONSHIP BETWEEN MES AND THE SUPPLY CHAIN

2. 3.2. CONTEXTUALIZATION OF BUSINESS SYSTEMS

2.3.3. CONCLUSION

3. 1. THE EVOLUTION OF MANUFACTURING STRATEGY

3. 1.1. GLOBAL COMPETITION

3. 1.2. AGILE MANUFACTURING

3. 1.3. CONCLUSION

3. 2. THE EVOLUTION OF MANUFACTURING PLANNING AND CONTROL SYSTEMS_ 37

3. 2.1. MATERIALS REQUIREMENTS PLANNING (MRP)

3. 2.2. CAPACITY REQUIREMENTS PLANNING (CRP)

3. 2.3. MANUFACTURING RESOURCE PLANNING (MRPII)

3. 2.4. ENTERPRISE RESOURCE PLANNING (ERP)

3. 2.5. PRODUCTION ACTIVITY CONTROL AND CLOSED LOOP MRP/MRPII 30

3. 2.6. MES CLOSES THE LOOP IN REAL-TIME

3. 2.7. NARROWING OF THE GAP FILLED BY MES

3. 2.8. CONCLUSION

3. 3. THE EVOLUTION IN INFORMATION TECHNOLOGY 56

3. 3.1. COMPUTER INTEGRATED MANUFACTURING (CIM) —

3. 3.2. BUSINESS MODELS OF MES AND CIM

3. 3.3. UNDERLYING TECHNOLOGY

3. 3.4. THE INTERNET 59

3. 3.5. OBJECT ORIENTATED PROGRAMMING AND CLIENT/SERVER TECHNOLOGY _ 61

3. 3.6. CONCLUSION 62 


\section{THE FUNCTIONS OF MES}

63

4. 1. FUNCTION MODEL FROM MESA INTERNATIONAL 65

4. 2. MCCLELLAN FUNCTION MODEL 68

4. 3. EVALUATION OF THESE MODELS 70

4. 3.1. FUNCTIONAL SILO MENTALITY

4. 3.2. THE OPPORTUNITY TO ABUSE THE TERM MES FOR MARKETING PURPOSES

4. 3.3. AMBIGUITY MAY OCCUR

4. 3.4. NEW FUNCTIONS EMERGE AS MES EVOLVE

4. 4. ALTERNATIVE FUNCTION MODEL

4. 4.1. DEVELOPMENT OF THE MES FUNCTION MATRIX

4. 4.2. EVALUATION AND VALIDATION OF THE MES FUNCTION MATRIX

4. 5. CONCLUSION

4. 5. CONCLUSION

\section{CASE STUDY: MES FUNCTION MATRIX AS TOOL TO EVALUATE DIAMES 89}

5. 1. BACKGROUND ON DIAMES

5. 2. THE EVALUATION OF DIAMES

5. 2.1. DIAMES AS PART OF THE MES AT ABEDARE CABLES

5. 2.2. DIAMES COMPARED TO OTHER MES

5. 3. THE MES FUNCTION MATRIX AS MES EVALUATION TOOL

5. 3.1. TOOL TO CONTEXTUALIZE MES PRODUCT COMBINATIONS

5. 3.2. TOOL TO IDENTIFY GAPS AND SUPPORT MAKE/ BUY DECISIONS 101

5. 3.3. TOOL TO INDICATE INTERFACE OR INTEGRATION

5. 3.4. TOOL TO ANALYZE INDUSTRY SPECIFIC MES FUNCTIONS

5. 3.5. TOOL TO COMPARE VARIOUS MES PRODUCTS WITH EACH OTHER

5. 3.6. TOOL TO SUPPORT OTHER MODELS

5. 4. CONCLUSIONS 108

5. 4.1. CONCLUSIONS REGARDING THE PRODUCT DIAMES

108

5. 4.2. THE USE OF THE MES FUNCTION MODEL AS MES EVALUATION TOOL 108

5. 4.3. FINAL CONCLUSION 110 110

\section{THE INDUSTRIAL ENGINEER IN THE MES ARENA 111}

\section{1. THE INDUSTRIAL ENGINEER}

6. 1.1. THE INDUSTRIAL ENGINEER AND MES

6. 1.2. THE INDUSTRIAL ENGINEER AND MES IN SOUTH AFRICA

6. 1.3. TRAINING OF THE INDUSTRIAL ENGINEER WITH REGARD TO MES

6. 2. ROLES WITHIN THE MES ARENA

6. 2.1. ROLES FULFILLED BY THE INDUSTRIAL ENGINEER

6. 3. THE INDUSTRIAL ENGINEER AS MES DEVELOPER
6. 3.1. DESIGNER/ PLANNER
6. 3.2. INNOVATOR/ INVENTOR
6. 3.3. CONCLUSION 
6. 4. THE INDUSTRIAL ENGINEER AS MES INTEGRATOR

6. 4.1. BOUNDARY/ SPANNER

6. 4.2. FACILITATER/ COORDINATOR/ CHAIRPERSON

6. 4.3. ANALYST

6. 4.4. DECISION MAKER

126

6. 4.5. PROJECT MANAGER

127

6. 4.6. TRAINER

128

6. 4.7. CONCLUSION 129

\section{USERS OF MES 130}

\section{0}

7. 1. THE USE OF MES WITHIN INDUSTRY SECTORS

7. 1.1. INDUSTRY SECTOR UTILIZATION OF RELATED SYSTEMS

7. 1.2. INDUSTRY SECTOR UTILIZATION OF MES WITHIN SOUTH AFRICA

7. 1.3. DRIVERS WITHIN INDUSTRY SECTORS

7. 1.4. MES FOR DISCRETE MANUFACTURING AND PROCESS MANUFACTURING

7. 1.5. INDUSTRIES OTHER THAN MANUFACTURING

7. 2. COMPANIES AS USERS OF MES

7. 3. THE USE OF MES WITHIN COMPANIES

7. 3.1. SHOP FLOOR OPERATORS

7. 3.2. PRODUCTION SCHEDULERS

7. 3.3. SUPPORT GROUPS : STOCK ROOM, TOOL ROOM, MAINTENANCE ENGINEERING

7. 3.4. CUSTOMER SERVICE AND SUPERVISORS

7. 3.5. MANAGERS \& MANUFACTURING ENGINEERING

7. 4. MES AS TOOL FOR THE INDUSTRIAL ENGINEER

\section{MES RESEARCHERS 145}

\section{1. CURRENT MES RESEARCH INITIATIVES}

8. 1.1. ADVANCED MANUFACTURING RESEARCH (AMR Research)

8. 1.2. MANUFACTURING EXECUTION SYSTEMS ASSOCIATION (MESA)

8. 1.3. NATIONAL INSTITUTE OF STANDARDS AND TECHNOLOGY (NIST)

8. 1.4. AMERICAN PRODUCTION AND INVENTORY CONTROL SOCIETY (APICS)

8. 1.5. AUTOMATION RESEARCH CORPORATION (ARC)

8. 1.6. NATIONAL CENTER FOR MANUFACTURING SCIENCES (NCMS)

8. 17. SAPICS (EDUCATIONAL SOCIETY FOR SUPPLY CHAIN MANAG

8. 1.8. OBJECT MANAGEMENT GROUP (OMG)

8. 1.9. SEMICONDUCTOR MANUFACTURING TECHNOLOGY (SEMATECH)

8. 2. PROPOSED ENVIRONMENT FOR RESEARCH INITIATIVE

8. 2.1. MES RESEARCH INITIATIVES IN SOUTH AFRICA

8. 2.2. RESEARCH INITIATIVES AT THE UNIVERSITY OF PRETORIA

8. 2.3. HOSTED BY THE DEPARTMENT OF INDUSTRIAL AND SYSTEMS ENGINEERING

8. 3. SCOPE OF THE PROPOSED RESEARCH INITIATIVE

8. 3.1. RESEARCH FIELDS

8. 3.2. FUNDING

8. 3.3. COORPORATION WITH INTERNATIONAL INSTITUTES

8. 3.4. SERVICES PROVIDED 
8. 4. THE ESTABLISHMENT OF A VIRTUAL RESEARCH FRAMEWORK__ 164

8. 4.1. POTENTIAL USERS OF THIS SERVICE

8. 4.2. SPECIFICATIONS 164

8. 4.3. LIST SERVER $\longrightarrow 166$

8. 5. CONCLUSION

\section{CONCLUDING CHAPTER 168}

9. 1. CONCLUSIONS ON GROUNDS ON OBJECTIVES 169

9. 1.1. INTEGRATE LITERATURE:MES BUSINESS MODELS AND APPLICATIONS __ 169

9. 1.2. INTEGRATE OPINIONS OF SOUTH AFRICAN ROLE PLAYERS 170

9. 1.3. DEVELOP A NEW OR COMBINED MODEL TO BE USED AS MES EVALUATION TOOL 170

9. 1.4. DEMONSTRATE THE VALIDITY OF THE NEWLY DEVELOPED MES MODEL THROUGH A CASE STUDY (DIAMES).

9. 1.5. RELATE MES TO INDUSTRIAL ENGINEERING _171

9. 1.6. INITIATE A RESEARCH PROGRAM FOR MES AT THE DEPARTMENT OF INDUSTRIAL AND SYSTEMS ENGINEERING (UNIVERSITY OF PRETORIA). _ـ 171

9. 2. CONTRIBUTION OF THIS DISSERTATION __ 172 